\title{
Удосконалення методики оцінки придатності використання будівельного піску як сировини для інших галузей промисловості
}

\begin{abstract}
Квариовий пісок є корисною копалиною багатоиільового призначення. Провідне місие як сировина у виробнищтві будівельних матеріалів посідає пісок. Поклади природних будівельних пісків України за зерновим складом і вмістом пиловидних та глинистих часток часто не відповідають показникам стандартів і потребують додаткового збагачення. Високі вимоги ставляться до хімічного складу пісків. Показники якості піску регламентуються відповідними нормативними документами залежно від галузі його використання. Більшість сучасних публікацій присвячена аналізу мінерально-сировинної бази промисловості будівельних матеріалів. Важливою є розробка рекомендачій, методики з визначення використання піску в певній галузі промисловості. В роботі було проаналізовано сировинну базу нерудних будівельних матеріалів Житомирського регіону та обтрунтовано галузі використання піску як сировини. Для розробки методики з оцінки родовища на придатність сировини для використання було використано технічні та якісні показники Паволоцького родовища будівельного піску Попільнянського району Житомирської області. За хімічним складом піски родовища досить однорідні, за мінералогічним складом легка фракиія представлена квариом до 99,7 \%, у незначній кількості польовим шпатом і халиедоном. Квариові зерна розміром менше за 0,63 мм складаються на $99 \%$ з квариу. Тонкі і дуже тонкі піски иього родовища є досить чистими і мають однорідний хімічний склад. Було сформовано систему показників якості піску з родовища порівняно $з$ нормативними показниками у вигляді таблиць. Ці таблиці слугують основою для вибору ринку збуту та технології і обладнання збагачення пісків. На основі аналітичної оцінки одержаних таблиць зроблено пропозиції щодо використання піску з Паволоиького родовища у будівельній галузі, скляній промисловості і при невеликих прочесах збагачення у виробництві формувальних виробів та тонкої кераміки. Представлену методику рекомендовано застосовувати і на інших природних родовищах.
\end{abstract}

Ключові слова: будівельний пісок; галузі промисловості; показники якості; нормативні документи; оцінка придатності.

Актуальність. Будівельні корисні копалини за об'ємом споживання є основним типом копалин, що потребує сучасна промисловість. Провідне місце серед цих копалин займає пісок. Природний пісок застосовується для приготування бетону, будівельних розчинів, виготовлення скла та абразивних матеріалів, формувальних виробів тощо. Основним споживачем піску є будівельна галузь України. Аналіз ситуації на ринку будівництва за останні п'ять років виявляс стрімке зростання обсягів будівництва на $60 \%$ і відставання у рості видобутку піску (40 \%) [1]. Якщо в найближчі роки темпи росту будівельних робіт не зменшатися, то виникне дефіцит піску. Для того щоб не допустити скорочення темпів будівництва, слід вживати заходи щодо нарощення обсягів видобутку природного піску.

Пісок належить до корисних копалин багатоцільового призначення. Щорічне споживання вимірюється мільйонами тонн. Вимоги до якості піску залежно від його призначення і використання визначаються відповідними нормативно-технічними документами. Пісок в основному використовують як заповнювач бетонів, асфальтобетонних сумішей для будівництва доріг, для влаштування баластового шару залізничних шляхів. В значних кількостях піски використовуються для виробництва будівельних розчинів, силікатних виробів автоклавного і безавтоклавного тверднення - силікатного каменю і цегли, щільних силікатних і ніздрюватих бетонів, у виробництві скла (скляні піски), під час ливарних робіт (формувальні піски). У відносно незначних кількостях піски використовуються для виробництва будівельної і тонкої кераміки, вогнетривів, абразивів, водопровідних фільтрів, як закладний матеріал під час рекультивації земель та іншого призначення. На території Житомирської області розвідано 342 родовища будівельної сировини. 3 них близько 30 піщаних та піщано-гравійних родовищ [2]. Пісок становить вагому частку видобувного комплексу будівельної сировини.

Разом з тим, під час освоєння нових родовищ або відновлення роботи вже існуючих піщаних кар'єрів використовуються дані апробації, що проводилася під час геологічної розвідки цих родовищ. 
У переважній більшості випадків геологічна розвідка проводилась ще у 70-80 роках минулого століття, а тому нормативні вимоги до піщаної сировини, які були чинними на той час, вже є застарілими. Для виконання геолого-економічної переоцінки запасів родовищ нерудних будівельних корисних копалин складається техніко-економічне завдання, в якому необхідно виконати оцінку придатності сировини для певної галузі промисловості. Але комплексно якісні характеристики піску не розглядаються. Тобто сировина може не задовольняти своїми показниками одну галузь промисловості і в той же час підходити для іншої.

Враховуючи таке важливе значення піску і використання його в різних галузях промисловості доцільним $\epsilon$ розроблення методики, на основі аналізу якісного складу природного родовища та стандартів на пісок, яка дозволить здійснювати рекомендації щодо використання піску в певній галузі промисловості. Саме тому в цій публікації розроблено методику оцінки придатності використання піску як сировини на прикладі Паволоцького родовища будівельного піску Попільнянського району Житомирської області.

Аналіз останніх досліджень та публікацій. Більшість сучасних досліджень присвячена аналізу мінерально-сировинної бази промисловості будівельних матеріалів України та використання кремнезему, відходів каменеобробної промисловості [3-5].

У працях закордонних авторів приділяється увага вивченню фізичних та хімічних властивостей піску, розробці нових методів дослідження. Так приводяться описова петрографічна класифікація піску, основана на квазіуніверсальному методі підрахунку крапок Газзі-Дікінсона, яка використовує потрійні композиції з кварцу, польового шпату та супутніх фрагментів, ця класифікація основана на геохімічних властивостях компонентів [6, 7]. Для вивчення фізичних властивостей піску, а саме пористості, пропонується застосування рентгеноструктурного аналізу. 3 використанням отриманих результатів аналізу діаметра пор рекомендується проводити тест на утримання води для дренажу [8-10].

Таким чином, більшість сучасних досліджень стосується властивостей та запасів піску, проте методика використання вивчених властивостей і стандартів для розробки класифікації та рекомендацій застосування піску як сировини залежно від потреб промисловості залишається маловивченою.

Мета роботи полягає у розробці теоретичних положень i практичних рекомендацій щодо придатності використання піску в певній галузі промисловості залежно від характеристики родовища. Досягнення мети передбачало формування та вирішення таких наукових і практичних завдань:

- проаналізувати сировинну базу нерудних будівельних матеріалів Житомирського регіону;

- дослідити та обгрунтувати області використання піску та вимоги до його якості;

- дослідити склад, класифікацію та оцінку якості піску на прикладі Паволоцького родовища

будівельного піску Попільнянського району Житомирської області;

- сформувати систему показників для оцінки придатності використання піску в певній галузі промисловості;

- ввести пропозиції щодо використання запропонованої методики при відносно невеликих процесах збагачення піску.

Викладення основного матеріалу. Нерудні корисні копалини - найбільш поширені в Україні як за кількістю видів, так і за кількістю відкритих та освоєних родовищ. Пояснюється це тим, що до них належать надзвичайно різноманітні за походженням породи й мінерали. Нерудні копалини широко використовуються у будівництві, науці й техніці, побуті та медицині. Вони є сировиною для багатьох галузей промисловості. За запасами деяких нерудних корисних копалин (сірки, облицювального каменю, каоліну) Україна посідає провідне місце в Європі, а за запасами графіту - друге в світі. Надзвичайно багаті надра України на природні матеріали, які використовуються в будівельній галузі. Одні 3 них ідуть на промислову переробку, інші безпосередньо спрямовуються на будівництво. Багато нерудних корисних копалин є сировиною для різних галузей промисловості.

Пісок становить вагому частку видобувного комплексу будівельної сировини. Із наведених даних випливає потреба у розвитку цієї галузі в межах Житомирської області. Це сприятиме розвитку будівництва та виготовлення будівельних матеріалів.

Пісок належить до корисних копалин багатоцільового призначення (рис. 1). Вимоги до якості піску для різних призначень їх використання визначаються відповідними нормативно-технічними документами. Природні піски України за зерновим складом і вмістом пиловидних та глинистих часток часто не відповідають вимогам стандартів і потребують збагачення - промивання і фракціонування.

Для виготовлення бетонів пісок використовується як дрібний заповнювач. Якісні показники заповнювачів визначають міцність бетонів і витрату цементу. Оцінка якості піску як дрібного заповнювача для важких бетонів проводиться згідно з ДСТУ Б В.2.7-32-95, ДСТУ Б В.2.7-43-96 щодо вимог до дрібних заповнювачів. Основні вимоги до піску для бетонів ставляться за зерновим складом і модулем крупності, який має бути від 1,5 до 3,25, а також за вмістом шкідливих домішок - кількість пиловидних і глинистих часток розміром менше 0,05 мм, що визначається відмучуванням, дозволяється до 3 \%. Кількість дрібних зерен, які проходять через сито 016, - до 15 \%. Колориметрична проба на вміст 
органічних домішок має надавати органічним домішкам забарвлення світліше за колір еталона. При техніко-економічний доцільності приготування бетонів з нормованими показниками якості допускається використовувати дуже дрібний пісок з модулем крупності 1,0-1,5 і вмістом зерна менше за 0,16 мм до $20 \%$.

Під час виготовлення бетонів спеціального призначення до піску ставляться вищі вимоги, які регламентуються відповідними стандартами: для бетонів дорожніх і аеродромних покриттів та основ, транспортного будівництва, гідротехнічних споруд, бетонних і залізобетонних труб - ДСТУ Б В.2.7-43-96; для жаротривких бетонів - ДСТУ ГОСТ 20190; для хімічно стійких бетонів - ДСТУ ГОСТ 25246.

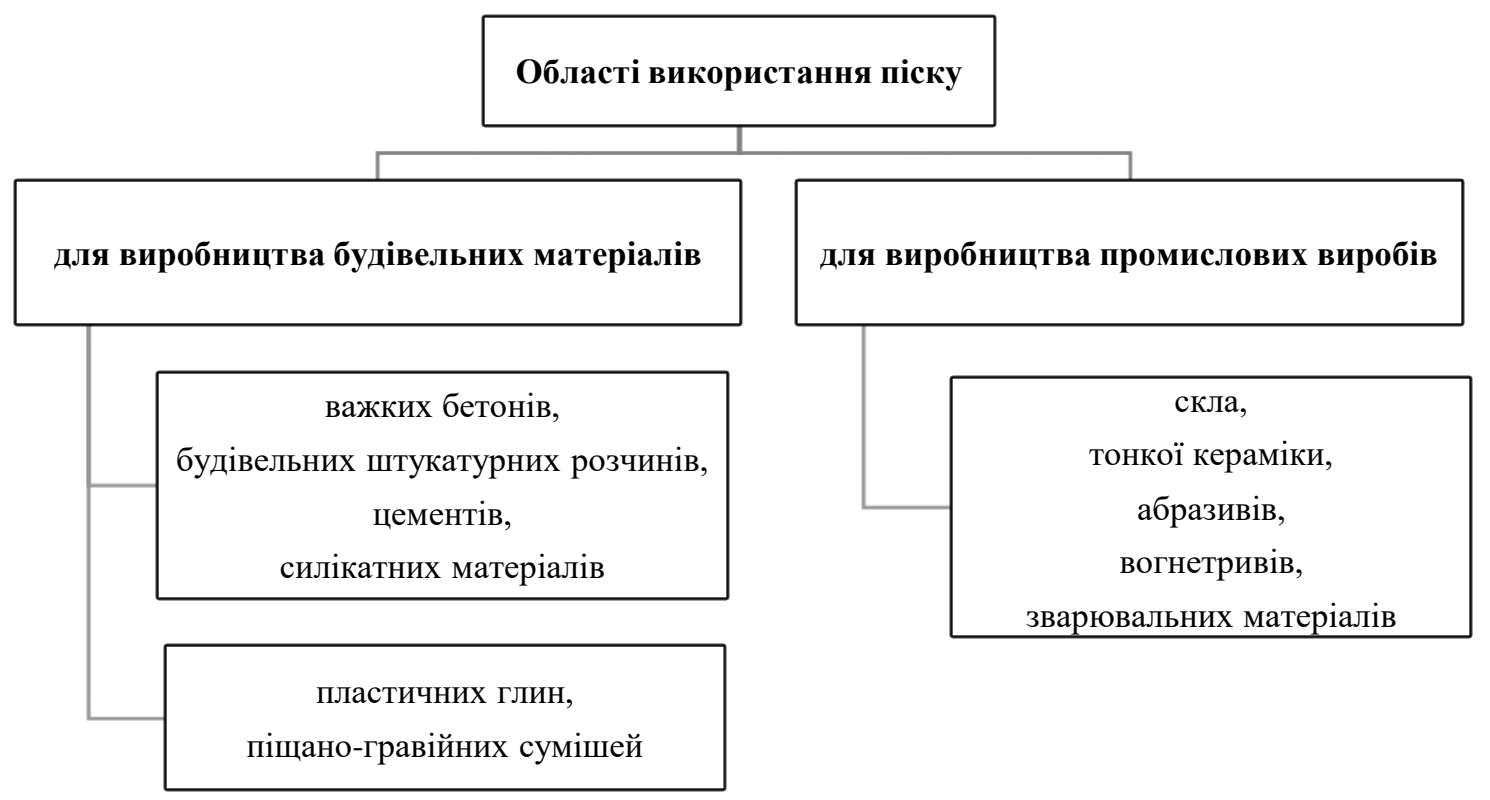

Рис. 1. Області використання піску

Для будівництва доріг використовуються природні та збагачені піщано-гравійні суміші у необробленому чи обробленому органічними або неорганічними в'яжучими речовинами стані.

Піщано-гравійні суміші мають відповідати вимогам ДСТУ ГОСТ 23735, ДСТУ ГОСТ 25607, ДСТУ ГОСТ 23558; піски - ДСТУ Б В.2.7-32.

Для всіх видів автодорожніх робіт регламентується зерновий склад заповнювачів, вміст пиловидних і глинистих часток, в тому числі глини в грудках; для цементобетонних покриттів - вміст потенційно реакційноздатних порід, які спроможні вступати в реакцію 3 лугами цементу. В цілому кількісні показники вимог коливаються в широких межах залежно від класів та шарів доріг, кліматичних умов, призначення матеріалів, умов експлуатації.

Найбільш жорсткі вимоги - до матеріалів для конструкційних шарів доріг високих класів, аеродромних покриттів. Для матеріалів дренувальних та мороз захисних основ додатково визначається коефіцієнт фільтрації.

Для улаштування баластового шару залізничної колї̈ використовується природна суміш гравію і піску, а також щебінь із гравію та валунів.

Оцінка якості гравійного і гравійно-піщаного баласту проводиться згідно з ДСТУ Б В.2.7-208:2009, яким нормується зерновий склад, вміст зерен міцних вивержених і метаморфічних порід не менше 50 \% і слабких (з міцністю менше за 19,6 МПа) не більше 10 \%; пиловидних і глинистих часток - до 2-3\%, зерен менше за 0,16 мм - до 10-15\%.

Для виготовлення будівельних $i$ штукатурних розчинів застосовуються піски, що відповідають за якістю вимогам ДСТУ Б В.2.7-32-95. Головні вимоги до якості піску для будівельних розчинів висуваються за зерновим складом 3 модулем крупності не більше за 2,2. Обмежується вміст фракцій розміром більше за 1,25 мм: до $5 \% 3$ масою для будівельних розчинів і до $0,5 \%$ за масою - для опоряджувального шару штукатурних розчинів, а також регламентується вміст пиловидних і глинистих часток до 7 \%, органічних і сторонніх домішок

У цементному виробництві піски використовуються як інертна і коригуюча добавка для різних видів портландцементів. Вимоги до якості пісків регламентовані «Техническими условиями на качество основных видов сырьевых материалов при производстве портландцементного клинкера» (МПБП СРСР; 1970 р.). Як інертна добавка до портландцементового клінкеру під час його помелу використовуються кварцові піски 3 вмістом $\mathrm{SiO}_{2}$ 80-95 \%. Кварцові піски використовуються як коригуюча добавка у 
цементну шихту для підвищення значення силікатного і зниження глиноземного модулів. При цьому придатність пісків визначається дослідним шляхом.

При виробництві силікатних будівельних матеріалів - силікатного каменю і цегли, армованих та неармованих виробів із щільних силікатних і ніздрюватих бетонів - піски застосовуються як заповнювачі та компонент в'яжучого. Технічні вимоги до пісків для виробництва силікатних виробів автоклавного тверднення регламентуються ДСТУ Б В.2.7-32-95. При цьому вимагається, щоб вміст кварцу (незв'язаного $\mathrm{SiO}_{2}$ ) у пісках для силікатних каменів і цегли та в'яжучого компоненту щільних силікатних бетонів не менше 50 \%, для ніздрюватих бетонів - не менше 70 \%. Також обмежується вміст пиловидних і глинистих часток для виробництва силікатних каменів і цегли до 20 \% (на заводах 3 імпортним обладнанням - до $10 \%$ ); для ніздрюватих бетонів - до $5 \%$; для щільних силікатних бетонів - до $3 \%$; сірчистих і сірчанокислих сполук у перерахунку на $\mathrm{SO}_{3}$ - до $2 \%$; слюди - до 0,5 \%; лугів у перерахунку на $\mathrm{Na}_{2} \mathrm{O}$ для ніздрюватих бетонів - до 2,7 \%; силікатних бетонів - до 3,6 \%; силікатної цегли - до 7,2 \%.

Вимоги до зернового складу пісків ставляться під час їх використання як заповнювачів для виготовлення щільного силікатного бетону та силікатних каменів і цегли. Зерновий склад пісків для решти призначень не нормується.

Піски використовуються як опіснювальна добавка до пластичних глин під час виробництва керамічних стінових матеріалів та інших формувальних виробів. Піски-опіснювачі мають бути достатньо крупними, мати невисокий вміст пиловидних і глинистих часток, не вміщувати шкідливих домішок карбонатних порід, гіпсу, гравію. Нормативних документів щодо якості піску для цього призначення не існує. Придатність його визначається за результатами випробувань готової продукції.

Якість пісків для скляної промисловості нормується вимогами ДСТУ Б В.2.7-131:2007. Для виробництва скла використовуються чисті дрібнозернисті кварцові піски однорідного складу з розміром зерен переважно від 0,1 до 0,8 мм. Високі вимоги висуваються до хімічного складу пісків - мінімальний вміст $\mathrm{SiO}_{3}$ допускається від $95 \%$ для низьких марок, до 99,8 \% для високих марок; вміст $\mathrm{Fe}_{2} \mathrm{O}_{3}$ обмежується 0,01-0,25\%, $\mathrm{Al}_{2} \mathrm{O}_{3}-0,4-4,0 \%$. Як правило, піски для виробництва скла переважно потребують збагачення; для цього найчастіше застосовуються флотовідтирання, іноді відтирання 3 промиванням або названі методи у поєднанні з електромагнітною сепарацією.

Формувальні піски використовуються як головний компонент суміші для ливарного виробництва. Вимоги до якості природних та збагачених пісків регламентуються ДСТУ ГОСТ 2138 та технічними умовами на природні формувальні піски конкретних родовищ.

Формувальні піски можуть бути кварцовими, при цьому під час виготовлення сумішей до них додаються пластифікатори: глини, бентоніт, рідке скло і глинистими-жирними; для останніх регламентується границя міцності на стиск. Формувальні піски повинні мати високу газопроникність, що забезпечується зосередженою зерновою структурою і обкатаністю зерен; достатньою вогнетривкістю, яка визначається високим вмістом кремнезему і низьким - оксидів лужних та лужноземельних металів і заліза; бути чистими - без шкідливих домішок сульфідної сірки, органіки тощо.

Для сталевого і чавунного литва використовуються кварцові крупно-, і середньозернисті піски 3 вмістом $\mathrm{SiO}_{2}$ 90-97 \%, оксидів заліза до 1,5\%, оксидів лужних та лужноземельних металів до 2,0 \% і глинистої складової $2 \%$.

Піски у фарфоро-фаянсовому виробництві використовуються як компонент сировинної суміші для зменшення усадки керамічних виробів. Вимоги до якості піску для тонкої кераміки регламентовані ДСТУ ГОСТ 7031-91.

Головна вимога до піску - чистота його хімічного складу: вміст $\mathrm{SiO}_{2}$ не менше за 93-95 \%; низький вміст фарбувальних оксидів $\mathrm{Fe}_{2} \mathrm{O}_{3} \mathrm{i} \mathrm{TiO}_{2}$. Для остаточної оцінки якості пісків необхідне проведення відповідних технологічних випробувань.

Як абразивний матеріал піски використовуються для шліфування скла, в піскоструминних апаратах - для очищення поверхні металу і облицювального каменю, в ливарній і будівельній промисловості - для виробництва штучного абразивного матеріалу - карборунду. Вимоги до якості піску для названих призначень установлюються ГОСТ 3647-88. Для абразивних цілей використовуються піски 3 гострокутними зернами ізометричної форми. Крупність піску залежить від його призначення. Для виробництва карбіду кремнію придатний кварцовий пісок із вмістом $\mathrm{SiO}_{2}$ не менше 98,5 \%; домішок не більше: $\mathrm{Fe}_{2} \mathrm{O}_{3}-0,3 \% ; \mathrm{Al}_{2} \mathrm{O}_{3}-0,5 \%$ i $\mathrm{CaO}-0,3 \%$.

Для виробництва зварювальних матеріалів придатний кварцовий пісок із вмістом $\mathrm{SiO}_{2}$ не менше 97 \%, фосфору - не більше 0,015 \% і сірки - сліди. Інші домішки дозволяються у кількості не більше $3 \%$.

У виробництві вогнетривів пісок застосовується у невеликій кількості під час виготовлення динасу, добавка у шихту для підвищення вогнетривкості і полегшення формування сирцю, а також для виготовлення набивних мас для футерування сталерозливних ківшів. Вимоги до якості пісків для виробництва вогнетривів регламентуються ТУ 14-8-223-77. Для цього найбільш придатні піски із середніми (0,5-1,0 мм) гострокутними зернами. Шкідливими домішками є слюда і польовий шпат, які зменшують температуру плавлення. Обмежується вміст $\mathrm{Fe}_{2} \mathrm{O}$ та $\mathrm{Al}_{2} \mathrm{O}_{3}$. 
Для розробки методики з оцінки родовища на придатність сировини для використання в певній галузі промисловості були використані технічні показники Паволоцького родовища будівельного піску, яке знаходиться в 0,8 км від південно-східної околиці с. Паволоч Попільнянського району Житомирської області, на правому березі р. Роставиця, яка є лівою притокою р. Рось і протікає в 0,8 км від родовища.

За геологічною будовою та своїм підпорядкуванням Паволоцьке родовище піску належить до морено-зандрової рівнини, рельєф якої ускладнений лесовими останцями і характеризується наявністю в верхній частині розрізу товщі порід верхньочетвертинного віку, які представлені еолово-делювіальними утвореннями, та потужної товщі середньочетвертинних порід, які представлені зандровими відкладами льодовикових озер, боліт та водних потоків. У геологічній будові беруть участь середньочетвертинні та верхньочетвертинні утворення (табл. 1).

Таблиця 1

Характеристика геологічної будови Паволоцького родовища

\begin{tabular}{|c|l|c|}
\hline $\begin{array}{c}\text { № } \\
\text { 3/п }\end{array}$ & \multicolumn{1}{|c|}{ Характеристика } & \multicolumn{1}{|c|}{$\begin{array}{c}\text { Потужність, м } \\
\text { (від - до) }\end{array}$} \\
\hline 1 & Грунтово-рослинний шар, суглинистий & $0,3-0,5$ \\
\hline 2 & $\begin{array}{l}\text { Суглинки лесовидні, жовто-бурого, палевого, } \\
\text { сірувато-палевого кольору, середньо пилуваті, легкі, } \\
\text { досить піскуваті, карбонатні } 3 \text { призматичною } \\
\text { структурою і дрібними кремнисто-карбонатними } \\
\text { конкреціями }\end{array}$ & $0,4-5,5$ \\
\hline 3 & $\begin{array}{l}\text { Піски (корисна копалина) від жовтого до коричневого } \\
\text { кольору, переважно дрібно-середньозернисті, } \\
\text { глинисті, щільні з вохристими плямами гідроокису } \\
\text { заліза }\end{array}$ & 4,0-12,3 \\
\hline 4 & $\begin{array}{l}\text { Суглинки озерно-льодовикові жовтого, буровато- } \\
\text { повтого кольору, ділянками 3 окремими сірими } \\
\text { плямами, тонкі на дотик, середні на вагу, пилуваті }\end{array}$ & $1,0-3,2$ \\
\hline
\end{tabular}

Піски деяких родовищ України вміщують цінні мінерали (ільменіт, рутил, циркон, монацит та ін.), а також потенційно можуть вміщувати золото і алмази у концентраціях, що дають змогу здійснювати оцінку комплексних промислових розсипів. Така оцінка має виконуватися на основі інструкцій ДКЗ України по застосуванню Класифікації запасів до розсипних родовищ.

За результатами гранулометричного аналізу, вивчені піски характеризуються як дуже тонкий i тонкий, дуже дрібний, дрібний пісок. Для класифікації пісків за зерновим складом наведено дані за результатами аналізів:

- модуль крупності пісків коливається від 0,2 до 1,48, середній модуль - 0,82;

- вміст зерен, що проходять крізь сито 0,16 мм, від 10,9 до 85,2 \%;

- пиловидних і глинистих від 0,3 до 65,6 \%, середній - 24,4\%.

Відповідно до класифікації ДСТУ за модулем крупності в загальній масі пісків 73,5 \% складають піски, що належать до групи тонкий пісок, 3,5 \% складають дуже тонкий пісок, 17,5 \% складають дуже дрібний, дрібний 5,5\%. Вміст пилуватих і глинистих часток у випробуваних пробах коливається від 0,3 до $65,6 \%$, середній $24,4 \%$.

За фізико-механічними властивостями пісків Паволоцьке родовище поділяється на дві частини. Південно-західна частина - потужність в цій частині родовища коливається від 4,0 м до 10,0 м, середня складає 7,3 м. Друга частина родовища - північно-східна - потужність пісків у цій частині родовища коливається від 8,0 м до 12,3 м, середня потужність - 9,6 м, нижня частина піску обводнена.

В цілому за хімічним складом піски досить однорідні (табл. 2). За результатами мінералогічного складу встановлено, що легка фракція представлена кварцом від 96,8 до 99,7 \%, у незначній кількості польовим шпатом і халцедоном.

Характеристика речовинного складу пісків родовища

Таблиияя 2

\begin{tabular}{|c|c|}
\hline Компоненти & Вміст у \%, \% на висушену речовину при 100 \\
\hline $\mathrm{SiO}_{2} \mathbf{C}$ від - до \\
\hline $\mathrm{K}_{2} \mathrm{O}$ & $84,35-95,36$ \\
\hline $\mathrm{Na}_{2} \mathrm{O}$ & $0,12-0,79$ \\
\hline $\mathrm{SO}_{3}$ & $0,055-0,380$ \\
\hline $\mathrm{H}_{2} \mathrm{O}$ & $0,020-0,030$ \\
\hline
\end{tabular}


Темноколірні мінерали у незначній кількості представлені ільменітом, глауконітом, гранатом, турмаліном. Дані про хімічний і мінеральний склад піску свідчить про відсутність шкідливих домішок. Вміст сірки, сульфідів, сульфатів у перерахунку на $\mathrm{SO}_{3}$ в немитому піску становить 0,020-0,030 \% при допустимому до $1 \%$. Таким чином, піски родовища однорідні за мінеральним та хімічним складом.

Використовуючи дані хімічного аналізу та фізико-хімічних властивостей пісків дослідницької лабораторії Житомирської геологічної експедиції було здійснено оцінку гранулометричного складу піску, вмісту зерен кварцу, польового шпату, ільменіту, рутилу та оксидів феруму у фракціях піску 3 родовища (рис. 2-8).
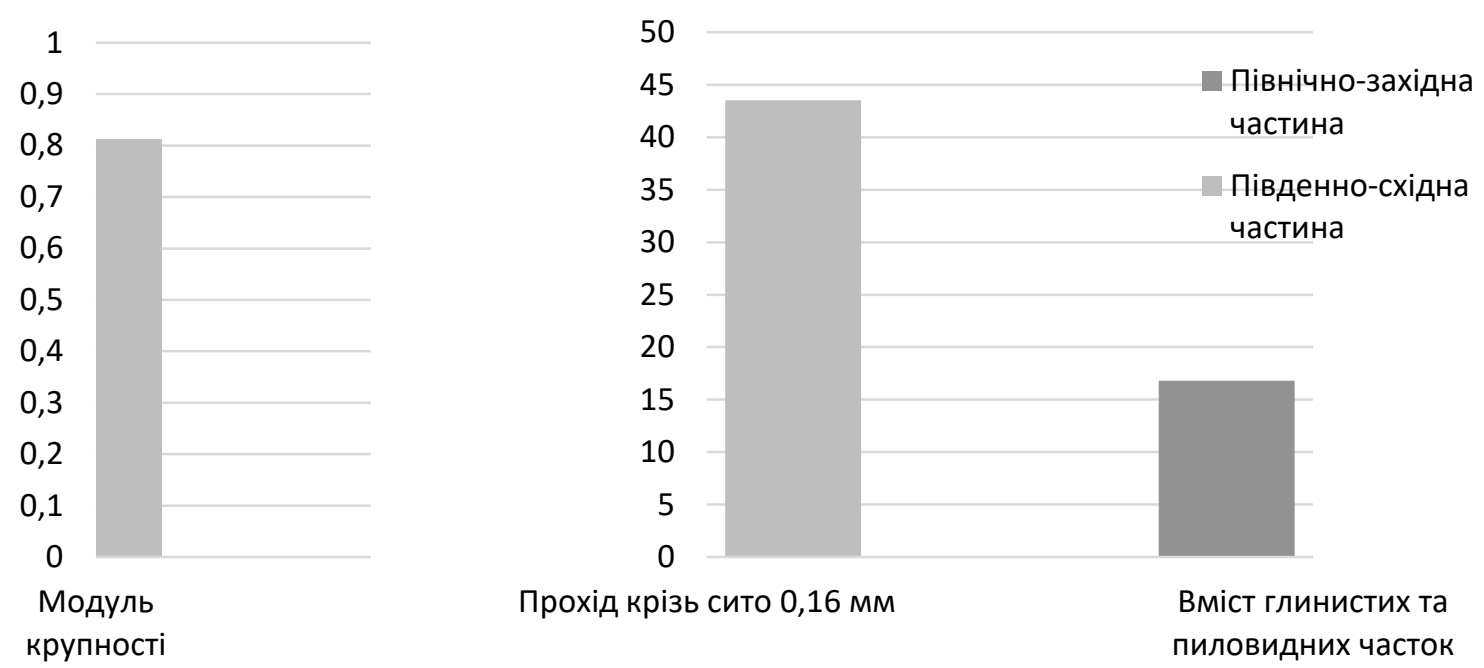

Рис. 2. Основні показники гранулометричного складу пісків

3 діаграм видно, що у північно-західній частині родовища піски дещо крупніші. Разом 3 тим, у південно-східній частині родовища піски більш забруднені глинистими та пилуватими частинками.

Аналіз вмісту кварцових зерен за фракціями показав, що зерна розміром менше за 0,63 мм складаються на більш ніж 99 \% 3 кварцу. Тобто тонкі і дуже тонкі піски цього родовища є досить чистими і мають однорідний хімічний склад. Для скляної промисловості вміст оксидів феруму, титану, алюмінію досить жорстко регламентується. Як бачимо 3 діаграм (рис. 4, 6, 8), у дуже тонкій фракції спостерігається відносно великий вміст цих металів. Як видно $з$ наведеного аналізу, піски Паволоцького родовища становлять перспективу використання у різних галузях промисловості.

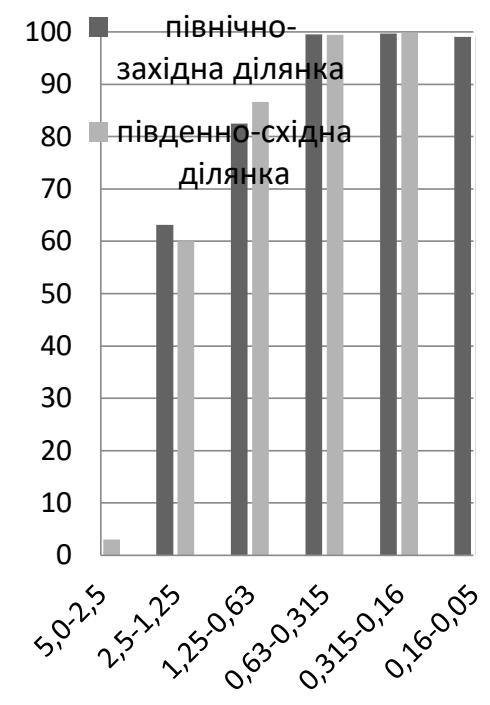

Рис. 3. Вміст кварияових зерен за фракціями, \%

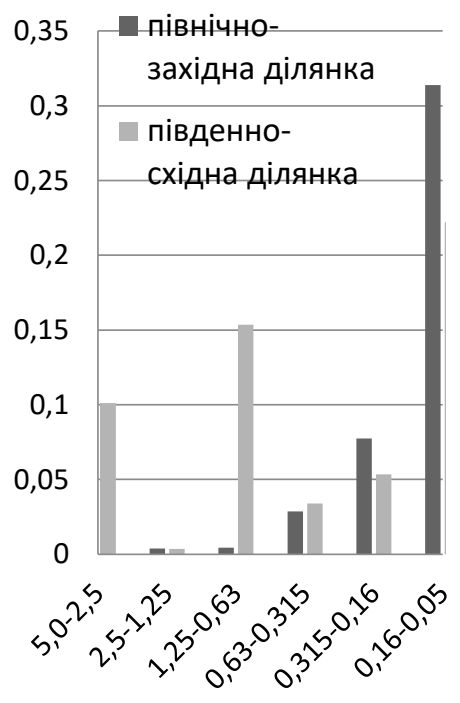

Рис. 4. Вміст зерен з вмістом феруму за фракиіями, \% 


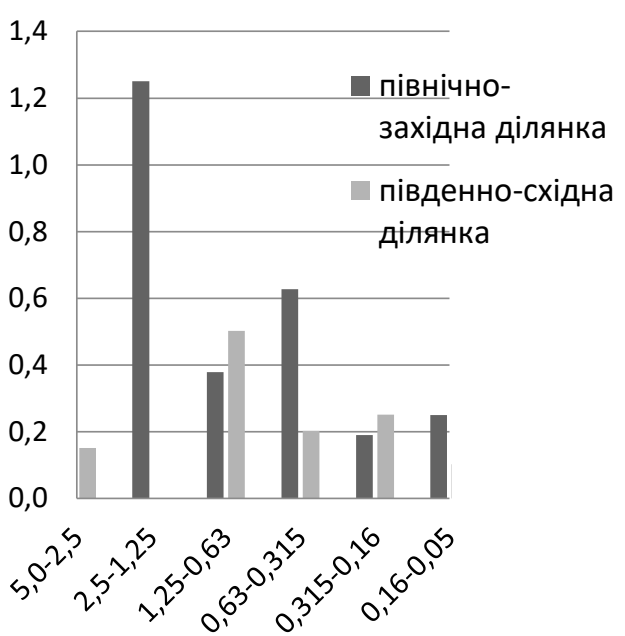

Рис. 5. Вміст зерен польового шпату за фракціями, \%

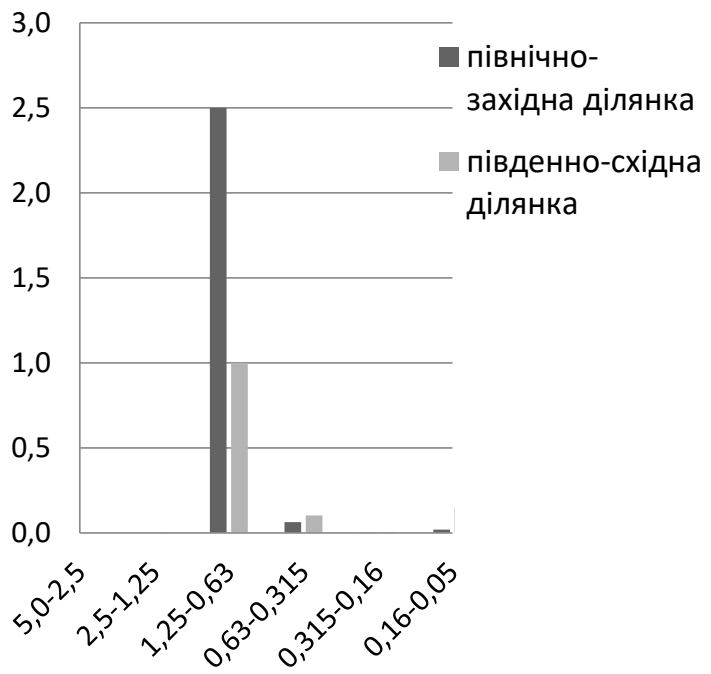

Рис. 7. Вміст зерен слюди за фракціями, \%

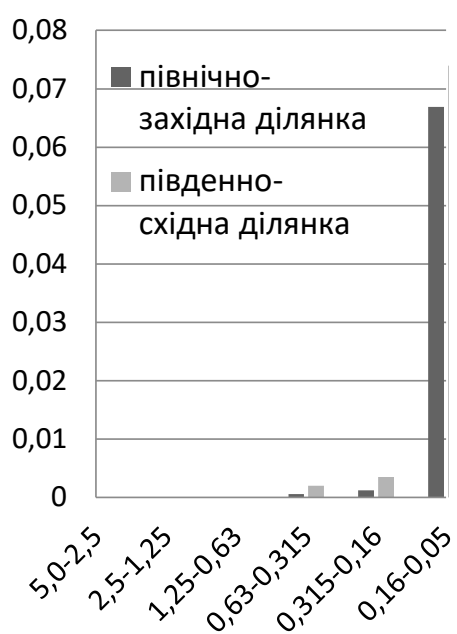

Рис. 6. Вміст зерен ільменіту за фракиіями, \%

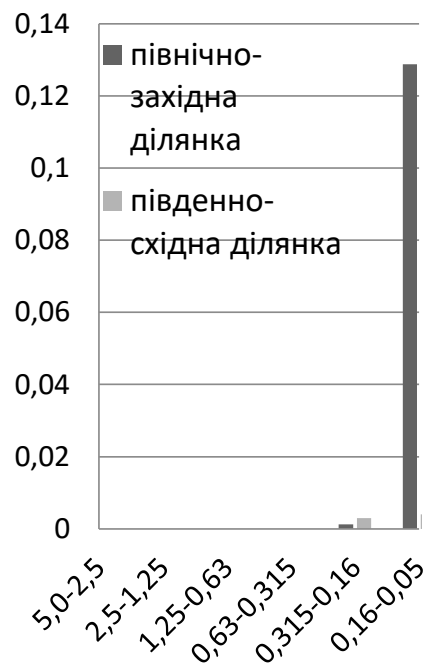

Рис. 8. Вміст зерен рутилу за фракціями, \%

3 метою формування системи показників для оцінки придатності використання піску в певній галузі промисловості та розробки відповідних пропозицій щодо його використання на основі розглянутих вище вимог та стандартів, які ставляться до піщаної сировини, були складені таблиці із граничними показниками. Ці таблиці слугуватимуть основою для вибору ринку збуту та технології і обладнання збагачення цих пісків. Було проведено дослідження на придатність піску з Паволоцького родовища для використання у виробництві будівельних матеріалів, скляних виробів, формувальних виробів і тонкої кераміки.

Як вже зазначалося, вимоги до піску для використання у виробництві будівельних матеріалів регламентуються державним стандартом ДСТУ Б В. 2.7.-32-95. Цей стандарт поширюється на щільний

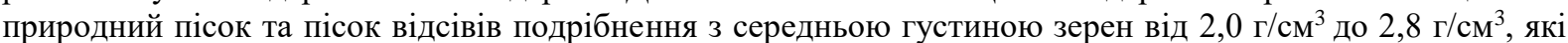
одержують із гірських порід, що спеціально чи попутно видобувають, і відходів гірничо-збагачувальних підприємств для використання як:

- дрібний заповнювач бетонів (важких, легких, дрібнозернистих, спеціального призначення та ін.), будівельних розчинів, сухих сумішей;

- заповнювач та компонент в'яжучого для виробництва силікатних бетонів щільної структури, ніздрюватих бетонів автоклавного і безавтоклавного тверднення, силікатних цегли, каменів та інших пресованих виробів;

У стандарті вказано обов'язкові вимоги, які спрямовані на забезпечення показників міцності, довговічності, морозостійкості продукції, а також її безпеки для здоров'я населення та навколишнього 
середовища і викладені у певних розділах. Ці вимоги були зведені у вигляді таблиці, користуючись якою був здійснений аналіз на відповідність піску із родовища (табл. 3).

Таблиия 3

Вимоги до піску згідно з ДСТУ Б В.2.7-32-95. Пісок щчільний природний для будівельних матеріалів

\begin{tabular}{|c|c|c|c|c|c|c|c|c|}
\hline Показник & 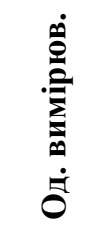 & 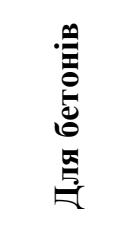 & 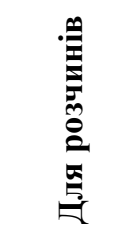 & 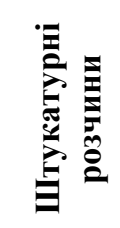 & 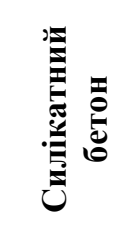 & 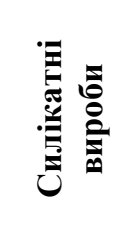 & 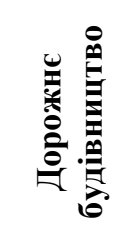 & 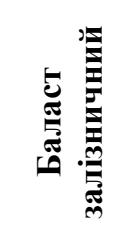 \\
\hline Густина зерен & $\Gamma / \mathrm{cm}^{3}$ & $2,0-2,8$ & $2,0-2,8$ & $2,0-2,8$ & $2,0-2,8$ & $2,0-2,8$ & $2,0-2,8$ & $2,0-2,8$ \\
\hline Насипна густина & $\kappa \Gamma / \mathrm{M}^{3}$ & 1100 & 1100 & 1100 & 1100 & 1100 & 1100 & 1100 \\
\hline Модуль крупності & & $1,0-4,0$ & $<2,2$ & $<2,2$ & $1,6-3,15$ & $0,5-2,75$ & - & - \\
\hline \multicolumn{9}{|l|}{ Зерновий склад } \\
\hline більше за 10 мм & $\%$ & $<0,5$ & 0 & 0 & $<0,5$ & $<0,5$ & $<0,5$ & $<20$ \\
\hline $5-10 \mathrm{MM}$ & $\%$ & $<5$ & $<0,5$ & 0 & $<5$ & $<5$ & $<5$ & $<50$ \\
\hline $2,5-5 \mathrm{MM}$ & $\%$ & - & - & 0 & $<20$ & $<15$ & - & - \\
\hline $1,25-2,5 \mathrm{~mm}$ & $\%$ & - & - & $<0,5$ & $5-45$ & $<20$ & - & - \\
\hline $0,63-1,25 \mathrm{MM}$ & $\%$ & - & - & - & $20-70$ & $5-60$ & - & - \\
\hline $0,315-0,63 \mathrm{мм}$ & $\%$ & - & - & - & $50-80$ & $15-80$ & - & $<65$ \\
\hline $0,16-0,315$ мм & $\%$ & - & - & - & $85-100$ & $30-100$ & - & $<15$ \\
\hline менше за 0,16 мм & $\%$ & $<10$ & $<20$ & $<20$ & $<15$ & $<70$ & $<20$ & $<15$ \\
\hline $\begin{array}{c}\text { Глинисті і } \\
\text { пиловидні частинки }\end{array}$ & & $<3$ & $<7$ & $<7$ & $<15$ & $<20$ & $<7$ & $<3$ \\
\hline \multicolumn{9}{|l|}{ Хімічний склад } \\
\hline $\mathrm{SiO}_{2}$ & $\%$ & - & - & - & $>50$ & $>50$ & - & - \\
\hline $\begin{array}{c}\mathrm{Na}_{2} \mathrm{O} \text { (по } \\
\text { перерахунку) }\end{array}$ & $\%$ & - & - & - & $<3,6$ & $<7,2$ & - & - \\
\hline $\mathrm{SO}_{3}$ (по перерахунку) & $\%$ & $<4$ & $<4$ & $<4$ & - & - & - & - \\
\hline
\end{tabular}

Примітка: тут кольори означають:

характеристики піску умовно відповідають вимогам;

характеристики піску повністю відповідають вимогам

характеристики піску близькі до відповідних вимог і потребують збагачення;

характеристики піску значно відрізняються від вимог

На основі проведеного аналізу можна зробити такі висновки. Пісок з північно-західної частини родовища придатний до виготовлення силікатних виробів без будь-якої підготовки. Також при зниженні вмісту часточок розміром менше за 0,16 мм до $15 \%$, а пиловидних та глинистих частинок до $7 \%$ пісок буде придатний до використання як сировина під час виготовлення будівельних розчинів та сухих будівельних сумішей, штукатурних розчинів, силікатного бетону та під час дорожнього будівництва.

Вимоги до природного та штучного піску, що використовується у скляній промисловості, регламентуються ДСТУ Б В.2.7-131:2007. Вимоги до пісків, які можуть бути використані під час виробництва формувальних виробів, регламентуються ДСТУ ГОСТ 2138-92. Для встановлення придатності піску різних фракцій Полоцького родовища для використання у скляній промисловості та у виробництві формувальних виробів був проведений відповідний аналіз показників зі складанням таблиць відповідності стандартам. Процедура однотипна. Різними кольорами виділялися показники піску, які відповідали заданим стандартам, що потребували певної процедури збагачення, та такі, які не відповідали стандартам.

Дослідження показали, що пісок родовища марки ПК-3, ПК-У можна використовувати як сировину для скляної промисловості. Якщо ж на збагачувальній фабриці застосувати відтирання та магнітну сепарацію, то можна використовувати і ПК-050-У. Пісок родовища може також використовуватися під час виробництва формувальних виробів, оскільки майже всі фракції мають високий вміст кварцу, коефіцієнт однорідності 60-70 \%, що відповідає вимогам стандарту. 
Також було вивчено можливість використання піску під час виробництва тонкої кераміки. При цьому вимоги до показників піску регламентуються ДСТУ ГОСТ 7031-91. Чисельні параметри вимог були зведені також у вигляді таблиці.

Потрібно зауважити, що для встановлення такої відповідності необхідно проводити додаткові аналітичні дослідження: втрати маси при прожарюванні та на вміст кальцій оксиду. Важливо також мати показники вмісту колірних оксидів, які зазвичай визначаються при відокремленні фракції - 0,16 мм. Оскільки саме у цій фракції максимальний вміст колірних оксидів та глинистих часточок. Проведені дослідження показали, що у природному стані пісок Паволоцького родовища можна також використовувати для виробництва тонкої кераміки.

Висновок. На основі аналізу хімічного та мінерального складу Паволоцького піщаного родовища та порівняння характеристик піску з нормативними показниками можна зробити висновок, що у випадку розділення піску на 3 фракції $(+2,5 ; 2,5-0,16 ;-0,16)$ його можна використовувати як сировину для: будівельних розчинів; силікатних бетонів; сухих будівельних сумішей; у дорожньому будівництві; у скляній промисловості; під час виготовлення формувальних виробів; під час виготовлення тонкої кераміки.

Наведену методику можна використовувати на будь-якому родовищі піску, складаючи таблиці відповідності хімічних та фізичних властивостей сировини відповідним показникам стандартів. На основі аналізу складених таблиць можна робити рекомендації щодо використання природної сировини у різних галузях промисловості. Також можна розробити вебсервіс для автоматичного визначення придатності піщаної сировини різним галузям промисловості.

\section{Список використаної літератури:}

1. Офіційний сайт Державної служби статистики України [Електронний ресурс]. - Режим доступу : http://www.ukrstat.gov.ua.

2. Мінеральні ресурси України. - Київ : Державне науково-виробниче підприємство «Державний інформаційний геологічний фонд України», 2014. - 270 с.

3. Андрєєва T.Є. Оптимальне використання сировинної бази підприємствами будівельного комплексу / Т.Є. Андреєва, О.П. Бутенко // Будівельне виробництво. - 2014. - № 57. - С. 17-24.

4. Prospects for using broken stone quarries waste / V.O. Shlapak, I.V. Klimenko, I.V. Davydova, O.S. Tarasyuk // Visnyk Zhytomyrs'kogo derzhavnogo tehnologichnogo universytetu / Serija : Tehnichni nauky. - 2018.№ 1 (81). -P. 302-308.

5. Онопрієнко B.B. Вплив кремнеземистого компоненту на формування споживчих властивостей силікатної цегли / В.В. Онопрієнко, П.В. Захарченко // Вісник Житомирського державного технологічного університету / Серія : Технічні науки. - 2016. - № 3 (78). - С. 164-171.

6. Eduardo Garzanti Petrographic classification of sand and sandstone / Eduardo Garzanti // Earth-Sciense Reviews. - 2019. - № 192. - P. 545-563.

7. Samir Mahmoud Zaid Provenance, diagenesis, tectonic setting, and geochemistry of Hawkesbury Sandstone (Middle Triassic), southern Sydney Basin, Australia / Samir Mahmoud Zaid, Fahad Al Gantani // Turkish J Earth Sci. - 2015. - № 24. - P. 72-98.

8. Surendra P. Verma New multi-dimensional diagrams for tectonic discrimination of siliciclastic sediments and their application to Precambrian basins / Surendra P. Verma, John S. Armstrong-Altrin // Chemical Geology. - 2013. № 355. - P. 117-133.

9. Effects of Sand Compaction and Mixing on Pore Structure and the Unsaturated Soil Hydraulic Properties / M.G. Mahmoodlu, A.Raoof. T.Sweijen, M.Th. van Genuchten // Vadose Zone Journal. - 2016. - T. 15, № 8. - P. 4-11.

10. X-ray CT analysis of pore structure in sand / Toshifumi Mukunokil, Yoshihisa Miyata, Kazuaki Mikami, Erika Shiota // Solid Earth. - 2016. - № 7. - P. 929-942.

\section{References:}

1. Oficijnyj sajt Derzhavnoi' sluzhby statystyky Ukrai'ny, [Online], available at: http://www.ukrstat.gov.ua

2. Derzhavnyj informacijnyj geologichnyj fond Ukrai'ny (2014), Mineral'ni resursy Ukrai'ny, Kyi'v, 270 p.

3. Andrjejeva, T.Je. and Butenko, O.P. (2014), «Optymal'ne vykorystannja syrovynnoi' bazy pidpryjemstvamy budivel'nogo kompleksu», Budivel'ne vyrobnyctvo, No. 57, pp. 17-24.

4. Shlapak, V.O., Klimenko, I.V., Davydova, I.V. and Tarasyuk, O.S. (2018), «Prospects for using broken stone quarries waste», Visnyk Zhytomyrs'kogo derzhavnogo tehnologichnogo universytetu, Serija Tehnichni nauky, No. 1 (81), pp. 302-308.

5. Onoprijenko, V.V. and Zaharchenko, P.V. (2016), «Vplyv kremnezemystogo komponentu na formuvannja spozhyvchyh vlastyvostej sylikatnoi' cegly», Visnyk Zhytomyrs'kogo derzhavnogo tehnologichnogo universytetu. Serija Tehnichni nauky, No. 3 (78), pp. 164-171.

6. Eduardo Garzanti (2019), «Petrographic classification of sand and sandstone», Earth-Sciense Reviews, No. 192, pp. $545-563$.

7. Samir Mahmoud Zaid and Fahad Al Gantani (2015), «Provenance, diagenesis, tectonic setting, and geochemistry of Hawkesbury Sandstone (Middle Triassic), southeirn Sydney Basin, Australia», Turkish J Earth Sci, No. 24, pp. $72-98$. 
8. Surendra P. Verma and John S. Armstrong-Altrin (2013), «New multi-dimensional diagrams for tectonic discrimination of siliciclastic sediments and their application to Precambrian basins», Chemical Geology, No. 355, pp. 117-133.

9. Mahmoodlu, M.G. Raoof, A., Sweijen, T. and van Genuchten, M.Th. (2016), «Effects of Sand Compaction and Mixing on Pore Structure and the Unsaturated Soil Hydraulic Properties», Vadose Zone Journal, Vol. 15, No. 8, pp. 4-11.

10. Toshifumi, Mukunoki1, Yoshihisa, Miyata, Kazuaki, Mikami and Erika Shiota (2016), «X-ray CT analysis of pore structure in sand», Solid Earth, No. 7, pp. 929-942.

Башинський Сергій Іванович, кандидат технічних наук, завідувач кафедри розробки родовищ корисних копалин ім. проф. М.Т. Бакка Державного університету «Житомирська політехніка».

Наукові інтереси:

- гірництво;

- сучасні методи видобутку та обробки каменю.

E-mail: ip_bass@i.ua.

Котенко Володимир Володимирович - кандидат технічних наук, доцент кафедри маркшейдерії; декан гірничо-екологічного факультету Державного університету «Житомирська політехніка».

Наукові інтереси:

- маркшейдерія;

- гірництво,

- технологія розробки покладів декоративного каменю.

Скиба Галина Віталіївна - кандидат технічних наук, доцент кафедри екології Державного університету «Житомирська політехніка».

Наукові інтереси:

- моніторинг якості об’єктів навколишнього середовища;

- властивості матеріалів.

http://orcid.org/0000-0001-8765-8849.

E-mail: skybagalyna26@gmail.com.

Колодій Марина Анатоліївна - старший викладач кафедри розробки родовищ корисних копалин ім. проф. М.Т. Бакка, Державного університету «Житомирська політехніка».

Наукові інтереси:

- дослідження міцності деталей машин;

- крихких гірських порід та інших крихких матеріалів.

E-mail:kgt_kma@ztu.edu.ua.

Остафійчук Неля Миколаївна - старший викладач кафедри розробки родовищ корисних копалин ім. проф. М.Т. Бакка Державного університету «Житомирська політехніка».

Наукові інтереси:

- гірництво;

- технології обробки і випробування каменю.

E-mail: onm.gef@ukr.net.

Стаття надійшла до редакції 09.04.2020. 